\title{
Éditorial
}

\section{Isocinétisme et fonction musculaire : de la prévention à la réhabilitation}

\author{
Pierre Louis Bernard ${ }^{1}$ et Francis Degache ${ }^{2}$ \\ 1 EA 2991 - Université Montpellier 1, France \\ 2 University of Applied Sciences Western Switzerland, Lausanne, Switzerland
}

Participer à un numéro spécial sur l'isocinétisme, c'est s'inscrire dans la dynamique questionnant les spécificités, les apports et les limites de cette technologie au service de la caractérisation de la fonction musculaire.

À la fin des années 1960, le concept d'exercice musculaire isocinétique introduit par Hislop et Perrine, propose de contrôler la vitesse d'exécution du mouvement en imposant une résistance à la contraction à tous les angles de l'amplitude articulaire. Depuis, les évolutions technologiques ont servi la poursuite et l'amélioration des principaux objectifs à savoir l'évaluation et le reconditionnement musculo-articulaire. De plus, Diversification et Validation sont allées de pair et pourraient être deux notions centrales caractérisant les démarches engagées depuis cet apport.

À partir de ces deux objectifs centraux d'évaluation et de reconditionnement préalablement cités, la diversification s'est appliquée de plusieurs façons parmi lesquelles l'introduction du mode de travail excentrique. Considéré comme une seconde révolution technologique par certains (Middleton, 2013), cet apport enrichit les démarches par l'ouverture à un travail mixte couplant travail concentrique et excentrique et par le calcul des ratios d'équilibre musculaire plus physiologique. La diversification concerne un nombre croissant d'articulations appendiculaires et tronculaires et donne accès à un nombre grandissant de paramètres témoignant des réponses et des adaptations musculaires. Cela n'ira pas sans une approche critique de validation sur laquelle nous reviendrons.

Diversification encore en terme de publics concernés, initialement orienté vers la réhabilitation, l'isocinétisme s'adresse en effet à des sujets déficients, à titre d'exemple à des problématiques de genou ligamentaire, de lombalgie ou d'épaule à conflits (ANAES, 2001; HAS, 2006). Il s'adresse aussi à des publics sains mais spécifiques tels que les personnes âgées ou les personnes sédentaires à des fins de prévention et d'optimisation ou encore à des sportifs à des fins de performance. Diversification enfin par l'association de technologies tels le recueil concomitant de l'activité électrique de surface des muscles agonistes et antagonistes impliqués dans le mouvement ou l'analyse des dommages et des réponses moléculaires.

Parallèlement à cette dynamique, l'approche méthodologique et critique de validation caractérisera l'évolution de la technique isocinétique. Des ouvrages de références tels que Isokinetics: muscle testing interpretation and clinical applications (Dvir, 1995) ou Isokinetics in human performance (Brown, 2000 et la participation d'auteurs de référence tels que Chandler, Davies, Ellenbecker) interrogeront régulièrement les conditions d'utilisation en terme d'installation et de positionnement du sujet vis-à-vis du dynamomètre, en terme de réglages ou de contrôle de la gravité.

Les protocoles retenus et les paramètres sélectionnés vont eux aussi régulièrement faire l'objet d'une approche critique. Avec des tentatives de consensus articulation par articulation sur les méthodologies d'usage, l'étude de la pertinence des analyses graphiques et chiffrées accompagne aujourd'hui régulièrement l'évolution de la technologie isocinétique et le sens à donner aux réponses et aux adaptations musculaires observées.

Ce numéro se compose d'articles méthodologiques et scientifiques, appliqués à des publics et/ou des articulations, illustrant l'application à des fins de prévention ou de réhabilitation. Il témoigne de la diversité et de la complémentarité des approches.

En première partie, ce numéro spécial présente trois contributions sur l'évolution de la technologie et son application, sur la recherche critique nécessaire des protocoles et des paramètres.

- Pierre Lemire (Medimex, France), définit l'origine de l'isocinétisme et retrace l'évolution de la technologie depuis les années soixante-dix. Il décrit son application progressive dans les actes d'évaluation et de 
réhabilitation et introduit les principaux paramètres chiffrés et graphiques.

- Zeevi Dvir (université de Tel Aviv, Israël), fort de son expertise et de son expérience, rappelle le statut de positionnement de « gold standard » de la dynamométrie isocinétique dans l'évaluation de la performance musculaire. Face à la diversité des rapports produits suite aux tests et à la multiplication des paramètres chiffrés de quantification du travail musculaire disponibles, l'auteur nous met en garde et réalise une approche critique de variables qu'il considère au mieux comme redondantes et au pire comme trompeuses.

- Pierre Louis Bernard, Hubert Blain, Guillaume Tallon, Sofiane Ramdani (Movement to Health $(\mathrm{M} 2 \mathrm{H}), \quad$ Euromov, université Montpellier ; département de Médecine Interne et de Gériatrie, CHU Montpellier, France) abordent, dans un article en trois parties, la complémentarité des démarches de validation d'une part et d'application à des publics spécifiques d'autre part. Les analyses de la validité du paramètre de temps de développement de la force maximale et de l'influence des temps de récupération sur les niveaux de force développée servent l'objectif méthodologique de validité des démarches. La caractérisation des adaptations musculaires de personnes âgées suite à une activité physique programmée illustre l'application aux publics et l'objectivation des effets physiologiques.

La seconde partie est composée de travaux méthodologiques et scientifiques appliqués aux populations et au service des problématiques de performance, de soins ou de prévention.

- Philippe Codine (clinique la Pinède, France) interroge l'articulation entre recherche de performance sportive et prévention des accidents tendino-musculaires. S'il toujours difficile de valider si le déséquilibre musculaire est un élément déterminant de la performance ou une conséquence potentiellement délétère de l'entrainement, le compromis aujourd'hui acceptable semble la réalisation d'un renforcement global des agonistes et des antagonistes en concentrique associé à un renforcement spécifique des antagonistes en excentrique.

- Pascal Edouard, Vincent Grémeaux, Francis Degache, David Gasq et Paul Calmels (hôpital Bellevue, CHU de Saint-Etienne, France; laboratoire de physiologie de l'exercice EA 4338, université de Lyon, France; Haute École de santé, université Lausanne, Suisse; CHU de Dijon et U1093 inserm de Dijon, France) traitent de l'intérêt de l'exploration des adaptations musculaires des rotateurs de l'épaule et de la balance musculaire des sportifs. À l'échelle d'une population, les sports de type armer-lancer ne semblent pas induire un déséquilibre musculaire prédisposant à la pathologie de l'épaule. Cependant, à l'échelle individuelle, la présence d'un déséquilibre musculaire doit être recherchée et doit influencée les contenus de préparation physique.
- Francis Degache (Haute École de santé, université Lausanne, Suisse) traite de la place de l'isocinétisme dans le processus de réhabilitation de l'insuffisance cardiaque chronique. Il justifie d'une évaluation précise et sécuritaire et d'une quantification des bénéfices des programmes de réadaptation. Cependant, l'évaluation en mode isocinétique induit des réponses cardio-vasculaires élevées nécessitant des précautions lors des évaluations de la force maximale. L'adaptation des protocoles constitue un besoin favorable au contrôle des réponses cardiovasculaires chez des personnes déficientes et déconditionnés.

- François Fourchet (université de Reims-Champagne, France) décrit l'usage et la pertinence de l'isocinétisme à des fins préventives et curatives et appliqués aux mouvements de flexion plantaire/dorsale et d'inversion/éversion du complexe pied-cheville. Le traitement des pathologies musculo-tendineuses du complexe suro-achilléen en mode excentrique est l'indication majeure d'usage de l'isocinétisme en flexion dorsale/plantaire. La prévention et la rééducation des entorses et des instabilités de cheville sont déterminantes en inversion/éversion. L'auteur insiste sur l'apport de la technique isocinétique pour les adolescents et sur la place de l'évaluation de la fatigue musculaire pour la prévention des blessures de surmenage liées à la pratique sportive intensive.

- Yannick Barthelemy, Jean-françois Kaux et Jean-marcel Ferret (centre de médecine du sport, Charleroi Sport Santé, Belgique; SPORTS ${ }^{2}$ et CHU de Liège; SPOREA, Lyon, France) traitent de la place de l'isocinétisme dans le domaine du sport de haut niveau et de son application à la traumatologie du sport. Son utilisation sert tout à la fois à identifier les profils à risque, à corriger les déséquilibres musculaires et à prévenir les blessures. Pour les pathologies musculo-tendineuses et ligamentaires, il complète les techniques kinésithérapiques et sert le suivi de la rééducation. Une prise en charge précoce par un travail isocinétique excentrique à vitesse lente, dans un but cicatriciel du tissu lésé, favorise la récupération fonctionnelle.

La troisième et dernière partie illustre l'apport de l'isocinétisme et l'appui qu'il représente lors d'association avec des méthodologies scientifiques d'investigation complémentaire de la fonction musculaire.

- Serge Colson (université de Nice Sophia Antipolis, France) évoque la pertinence mais l'usage encore peu fréquent du recueil concomitant de l'activité électrique des muscles agonistes et antagonistes impliqués dans le mouvement par électromyographie de surface (EMGs). L'auteur présente les méthodes de normalisation des signaux EMGs et leur influence sur les relations EMGs-angle et EMGs-vitesse angulaire lors de la production de moment. L'apport de cette méthode à la compréhension de l'état de la commande 
nerveuse est réel en réhabilitation et dans les sciences du mouvement humain.

- Pierre Portero, Stevy Farcy et Giuseppe Rabita (EAC CNRS 4396, université Paris Créteil, France; service de rééducation neuro-orthopédique, hôpital Rothschild, Paris, France; service Recherche, INSEP, Paris, France) présentent l'originalité des dynamomètres à caractériser, au delà des composantes classiques de la force, les propriétés mécaniques passives du système musculo-articulaire (SMA) tels que la raideur et la viscoélasticité. Ils montrent en quoi l'isocinétisme a permis d'améliorer la connaissance des facteurs altérant l'extensibilité du SMA.

- Stéphanie Hody, Bernard Rogister, Pierre Leprince, Jean Michel Crielaard, Zoé Lacrosse, Jean Louis Croisier (GIGA, université de Liège; département de neurology, CHU, université de Liège; département of motricity sciences, université de Liège; départment of physical medicine, CHU de Liège, Belgique) développent que lors d'un usage intense, l'exercice excentrique est classiquement à l'origine de courbatures d'apparition retardée nommées Delayed-Onset Muscle Soreness (DOMS). Pour optimiser les effets positifs du travail excentrique et limiter les courbatures, il est aujourd'hui retenu un entraînement excentrique à intensité sous-maximale progressivement intensifiée. Associé aux techniques de biologie moléculaire, l'isocinétisme constitue un modèle intéressant de génération et d'investigation des DOMS.

\section{Bibliographie}

Agence Nationale d'Accréditation et d'Évaluation en Santé. (2001). Les appareils d'isocinétisme en évaluation et en rééducation musculaire : intérêts et utilisation. ANAES.

Brown, L.E. (2000). Isokinetics in human performance. Human Kinetics.

Dvir, Z. (2004). Isokinetics : muscle testing, interpretation and clinical applications. $2^{\text {nd }}$ ed. Edinburgh : ElsevierChurchill Livingstone.

Haute Autorité de Santé. (2006). Mesure de la force, du travil et de la puissa,ne musculaire par dynamomètre informatise et motorisé. HAS.

Hislop, H.J., \& Perrine, J.J. (1967). The isokinetic concept of exercise. Physical Therapy, 47, 114-7.

Middleton, P. (2013). Éditorial. La révolution isocinétique. La Lettre de Médecine Physique et de Réadaptation, 29 (2), 53. 


\title{
Editorial
}

\section{Isokinetic and muscle function: from prevention to rehabilitation}

\author{
Pierre Louis Bernard ${ }^{1}$ and Francis Degache ${ }^{2}$ \\ ${ }^{1}$ EA 2991 - Université Montpellier 1, France \\ ${ }^{2}$ University of Applied Sciences Western Switzerland, Lausanne, Switzerland
}

Being part of a special issue about isokinetic it is as questioning the specific dynamics, the contributions and limitations of this technology about the different characteristics of the muscle function. In the late $60 \mathrm{~s}$, the concept of isokinetic muscle exercise has been introduced by Hislop and Perrine, concept that offers the possibility to control the execution speed of motion by imposing a resistance to a contraction at each angles of the motion. Since then, technological developments have helped the ongoing projects and improved the main goals which are the evaluation and the musculo-articular reconditioning. In addition, diversification and validation had a parallel evolution and could be two central notions characterizing the steps taken since this contribution.

From these two main goals which are evaluation and reconditioning mentioned above, the diversification started to be implemented in different ways but essentially the introduction of eccentric mode. This has been considerate as a second technological revolution for certain authors (Middleton, 2013). This revolution added to the use of functional muscular ratio (concentric and eccentric muscle performances) brought new way of research. This diversification can be applied to a growing numbers of appendicular and troncular articulations and then related directly to different parameters in response of the muscular adaptations. Unfortunately we have to take a critical stands towards this validation but we will come back on that point later on.

This term of diversification can be used also with concern persons, initially used with rehabilitation, isokinetics testing is commonly effective with pathological populations and particularly in ligamentary knees, low back pain of shoulder instability (ANAES, 2001; HAS, 2006). Actually, we use this technology for prevention and muscular reconditioning for elderly and sedentarily people, as well as for sports performance.

Finally, this term of diversification cannot be used only in the context of muscle evaluation but can be a complement with different associated technics as the electromyographic analysis of antagonist and agonist muscle during movement, or molecular responses and damage analysis.
A long with this dynamics, the evolution of isokinetic technic will be characterized by the methodological approach and the relevant validation. Key references such as Isokinetics: muscle testing interpretation and clinical applications (Dvir, 1995) or Isokinetics in human performance (Brown, 2000 and the participation of various authors such as Chandler, Davies, Ellenbecker) investigate regularly the use's conditions in term of the installation and the position of isokinetic dynamometer on the subjects, and even more in term of adjustments and gravity correction. By the way, the selected protocols and parameters are often criticized. Actually, there are established consensus for muscle evaluations in each articulation. Today, the graphical analysis cannot be taking apart from the numbered analysis and it is important to notice that they follow the evolution of isokinetic technology and give sense to muscular responses and adaptations.

This special issue consist in scientific and methodological articles, applied to specific publics or articulations, showing the interest in prevention and rehabilitation goals. It shows the diversification and the complementarity of these various approaches.

In the first part of this special issue, you will find three contributions about the evolution and the application of isokinetic technology, and the necessary questioning about optimal protocols and parameters selection.

- Pierre Lemire (Medimex, France), defines isokinetic origin and talks about technologic evolution since 70's. His progressive application in evaluation and rehabilitation acts, describes and introduces principals graphic and numbers parameters.

- Zeevi Dvir (University of Tel Aviv, Israel), with its strong expertise and experience, reminds that the isokinetic dynamometry in muscular performance evaluation remains the "gold Standard". This author presents the complexity of use exercise reports and the difficulty to choose between relevant parameters which quantify muscle performance. In this context, this author warns us and criticizes some various approaches being such as redundant and even wrong about the isokinetic parameters. 
- Pierre Louis Bernard, Hubert Blain, Guillaume Tallon, Sofiane Ramdani (Movement to Health (M2H), Euromov, University of Montpellier; Geriatric and internal medicine department; CHU Montpellier, France) explains, in an article divided in three different parts, the complementarity of validation processes on one hand towards the application to a specific public on the other hand. The analyses of the validity of the time at peak torque parameter and the influence of the recovery time on the levels of developed strength help us to validate the methodological objective of the various processes. The characterization of the muscular adaptations in elderly people after a programmed physical activity illustrates the isokinetic application to the public and the objectivation of physiological effects.

The second part of this special issue presents scientific and methodological articles applied specifically to specific populations in a performance, health and injury prevention context.

- Philippe Codine (clinique la Pinède, France) questions the link between research of sports performance and prevention of tendino-muscular injuries. It always remains difficult to validate if the muscular imbalance is a determining element of the performance or a potentially noxious consequence of the physical training, the most acceptable compromise seems, today, to be the realization of a global strengthening of agonist and antagonist muscles in concentric mode combined with a specific strengthening of the antagonists in eccentric.

- Pascal Edouard, Vincent Grémeaux, Francis Degache, David Gasq et Paul Calmels (Bellevue Hospital, CHU de Saint-Etienne, France; Laboratory of exercise physiology EA 4338, University of Lyon, France; University of Health Sciences (HESAV), University of Applied Sciences and Arts Western Switzerland (HES-SO), Lausanne, CHU de Dijon et U1093 Inserm de Dijon, France) write about the exploration of the muscular adaptation of the shoulder rotator and the muscular balance of sports persons. Authors explain that SPORT ARMER LAMCE seem not to induce muscular imbalance predisposing shoulder injury. However, it is important to define muscular imbalance in each sports to optimize physical preparation content.

- Francis Degache (University of Health Sciences (HESAV), University of Applied Sciences and Arts Western Switzerland (HES-SO), Lausanne) deals with the goals of isokinetic testing in rehabilitation processes of chronic heart failure patients. Isokinetic testing must be precise and secure so that way they help to quantify rehabilitation program benefits. However, isokinetic testing induces very important cardiovascular responses requiring precautions during maximal strength evaluation. The adaptation of protocols constitutes a beneficial need to the control of cardiovascular responses in deconditioned and deficient people.

- François Fourchet (University of Reims-Champagne, France) describes the use and the relevance of isokinetic in preventive and curative goals especially when applied to plantar/dorsal flexion and inversion/eversion of foot-ankle complex. The treatment of the musculotendinous pathologies of suro-achilleen complex in eccentric mode must use plantar/dorsal flexion. Prevention and rehabilitation of sprains and ankle instabilities are the key determinant in inversion/eversion. Author focuses on the contribution of isokinetic technic for teenagers and on the importance of fatigue quantification for injury prevention induced by overwork bound to intensive sports practice.

- Yannick Barthelemy, Jean-françois Kaux et Jean-marcel Ferret (Centre of sports medicine, Charleroi Sport Santé, Belgium; SPORTS ${ }^{2}$ et CHU de Liège; SPOREA, Lyon, France) explain the importance of isokinetic in the top level sports area and its application in the sport traumatology. Its use help to identify profiles with risks, to correct muscular imbalance and to prevent injuries. For ligamentary and musculotendinous pathologies, isokinetic processes is combined with physiotherapy techniques and help the follow-up of rehabilitation. To improve functional recovery, when repairing injured tissue, it is recommended to work the earlier as possible with the eccentric isokinetic training with low angular velocities.

The third part of this special issue highlights the fact that isokinetic evaluation can be associated with specific investigation technics to explore muscular function.

- Serge Colson (University of Nice Sophia Antipolis, France) presents the relevance but still rare use of the concomitant collection of the electric activity by EMG of agonist and antagonist muscles implied in movement. Author presents EMGs signal normalization methods and its influence on EMGs/angle and EMGs/angular speed during a moment product. The contribution of this method in the understanding of nervous command state is important in rehabilitation and human movement sciences.

- Pierre Portero, Stevy Farcy et Giuseppe Rabita (EAC CNRS 4396 University of Paris Créteil, France; Neuroorthopaedic unit, Hôpital Rothschild, Paris, France; Research Unit, INSEP, Paris, France) present the originality of isokinetic dynamometers to caracterize, beyong classical component of strength, the passives mechanical properties of the musculo-articular system (SMA) such as muscle stifness and viscoelasticity. They show in what isokinetic allowed us to improve the knowledge of factors altering SMA extensibility.

- Stéphanie Hody, Bernard Rogister, Pierre Leprince, Jean Michel Crielaard, Zoé Lacrosse, Jean Louis Croisier (GIGA, University of Liège; Department of Neurology, CHU, University of Liège; Department of Motricity Sciences, University of Liège; Department of Physical Medicine, CHU de Liège, Belgium) explain that intensive eccentric exercise induces DelayedOnset Muscle Soreness (DOMS). To optimize positive 
effects of eccentric exercise and to limit the DOMS, an eccentric training with gradually intensified submaximal intensity remains the best way to work out. With molecular biological technics, isokinetic seems to be an interesting model of DOMS provocation and investigation.

\section{Bibliography}

Agence Nationale d'Accréditation et d'Évaluation en Santé. (2001). Les appareils d'isocinétisme en évaluation et en rééducation musculaire : intérêts et utilisation. ANAES.
Brown, L.E. (2000). Isokinetics in human performance. Human Kinetics.

Dvir, Z. (2004). Isokinetics: Muscle testing, interpretation and clinical applications. 2nd ed. Edinburgh: ElsevierChurchill Livingston.

Haute Autorité de Santé. (2006). Mesure de la force, du travail et de la puissane musculaire par dynamomètre informatise et motorisé. HAS.

Hislop, H.J., \& Perrine, J.J. (1967). The isokinetic concept of exercise. Physical Therapy, 47, 114-7.

Middleton, P. (2013). Éditorial. La révolution isocinétique. La Lettre de Médecine Physique et de Réadaptation, 29 (2), 53. 